\title{
India's outburst of online classes during COVID-19 impacts the mental health of students
}

\author{
Govindasamy Agoramoorthy ${ }^{1}$ (D) \\ Accepted: 13 April 2021 / Published online: 6 May 2021 \\ (C) The Author(s), under exclusive licence to Springer Science+Business Media, LLC, part of Springer Nature 2021
}

Many countries have closed down schools to combat the spread of COVID-19 infections that brought additional pressure on the mental health of school students (Guessoum et al., 2020; Lee, 2020; Loades et al., 2020). The pandemic has also affected the overall wellness of students across continents (Copeland et al., 2021). India harbors one of the largest student population of 315 million and nearly half of them are girls. The pandemic-induced lockdowns and curfews have led to the closure of all schools in India that eventually affected the students, both physically and mentally (Chorpita et al., 2020). According to the UNICEF, over 1.5 million schools were closed due to COVID-19 across India that directly impacted the students and teachers. The World Bank estimates that the sudden closure of schools to control the pandemic could cost India nearly USD 400 billion, which is an enormous economic loss (Singh, 2020).

India has enforced the lockdown from 24 March 2020 with just 4-h advance warning that continued for over two months. Then, the curfews followed for few months in some states that recorded more cases of infections. The strict lockdown measures forced the schools to shut down and therefore the mushrooming of online classes abruptly came into effect when the students were neither trained nor prepared for it. The most affected students belonged to the poorest section of the Indian socio-economic hierarchy where the parents depend on daily wages for survival. Over 140 million migrant workers have straightaway lost their jobs when the lockdown came into effect (Agoramoorthy \& Hsu, 2021). The abrupt lockdown policy not only shocked the daily wage workers, but also activated enormous mental pressure on their schoolgoing children. Sorrowfully, some students have ended up committing suicide to escape the mental torture inflicted through the insensitive policy.

Govindasamy Agoramoorthy

agoram@tajen.edu.tw

1 College of Pharmacy and Health Care, Tajen University, Yanpu, Pingtung 907, Taiwan
In June 2020, a 14-year-old girl student from an impoverished family belonged to the socially-suppressed Dalit community in Kerala State burnt herself to death by soaking herself with kerosene. Her father was unable to purchase a smartphone to access the online classes since he lost the job and left with no savings (Aljazeera, 2020). Similarly, a 16-year-old girl student from West Bengal State hanged herself to death because she didn't have a smartphone. She was fearful of failing in the final exam. In July 2020, a 14-year-old girl student from Tamil Nadu State committed suicide since she was unable to pay school fees. Her father lost the job due to the instant lockdown while the family didn't have any savings.

In August 2020, another high school student from Karnataka State killed herself as the impoverished parents were unable to provide her a smart phone to participate in the online classes. Also in September 2020, a high school student in Tamil Nadu State committed suicide by hanging after failing to cope with the pressure provoked by the online lessons. The student faced difficulties to understand the lectures online and worried about failing in the exam (Nath, 2020). The above cases portray the extreme stress scenarios catalyzed by the online classes to the adolescents during the peak of the pandemic. The absence of timely psychological counseling by professionals has further fueled the crisis.

According to the Human Development Report (2019), India is home to nearly 364 million poor people. Children from the poor families faced the maximum struggle to access online classes during the pandemic. Although India harbors over 1.3 billion people, only half the population has access to the internet. The weak signal in rural areas makes it more difficult to stream online class videos. Moreover, the erratic electric power supply makes it even more frustrating for the students to access class lectures via online. The government admits that only $47 \%$ of homes in the country have access to $12 \mathrm{~h}$ of electric power supply, while $36 \%$ of schools have no access to electricity at all. Also, only $8 \%$ of the homes with adolescents have computers connected to the internet (Kundu, 2020). In this murky reality, how is it possible to educate the 
millions of marginalized students online with efficiency and without provoking unnecessary psychological distress?

To add fuel to the flame, most schools in rural India where the impoverished students largely congregate lack psychological counselors. The enduring pandemic has further intensified the mental health complications among students that include anxiety, depression, suicide, conflicts, dropouts, and behavioral problems. Although the government mandates all schools to have counsellors, the policy has not been enforced vigorously. Critiques therefore argue that India must hire 1.5 million professional counsellors at the earliest to maintain the globally acceptable level of student-to-counselor ratio in schools (Ghosh, 2019).

India's health budget has persisted between 1.2 to $1.6 \%$ of the GDP from 2008 to 2020, which is one of the lowest in the world. Sadly, only $0.06 \%$ of the entire health spending has been allocated solely to solve mental health issues. When it comes to the care of a single mentally-ill person yearly, India spends only one USD, which portrays the chronic lack of money to tackle the inclusive mental health agenda in the world's largest democracy. Therefore, the government must allocate more funds and manpower to address the mental health problems faced by the students at the grassroots level before it is too late.

Authors' Contributions Single author contribution.

Data Availability Data sharing is not applicable to this article as no new data were created or analyzed in this study.

\section{Declarations}

Human Participants Informed Consent Not applicable.

Ethics Approval No human studies performed.

Conflict of Interest No potential conflict of interest was reported by the author.

\section{References}

Agoramoorthy, G., \& Hsu, M. J. (2021). How the coronavirus lockdown impacts the impoverished in India. Journal of Racial and Ethnic Health Disparities, 8, 1-6.

Aljazeera (2020). Unable to access online classes, Dalit girl kills herself. Retrieved March 11, 2021, from https://www.aljazeera.com/news/ 2020/6/3/india-unable-to-access-online-classes-dalit-girl-killsherself.

Chorpita, B. F., Daleiden, E. L., Malik, K., Gellatly, R., Boustani, M. M., Michelson, D., Knudsen, K., Mathur, S., \& Patel, V. H. (2020). Design process and protocol description for a multi-problem mental health intervention within a stepped care approach for adolescents in India. Behavioral Research Theraphy, 133, 103698.

Copeland, W. E., McGinnis, E., Bai, Y., Adams, Z., Nardone, H., Devadanam, V., Rettew, J., \& Hudziak, J. J. (2021). Impact of COVID-19 pandemic on college student mental health and wellness. Journal of the American Academy of Child and Adolescent Psychiatry, 60(1), 134-141.

Ghosh, R. (2019). India needs 15 lakh counsellors for 315 million students. Retrieved March 11, 2021, from https://timesofindia. indiatimes.com/home/education/news/india-needs-15-lakhcounsellors-for-315-million-students/articleshow/69201566.cms.

Guessoum, S. B., Lachal, J., Radjack, R., Carretier, E., Minassian, S., Benoit, L., \& Moro, M. R. (2020). Adolescent psychiatric disorders during the COVID-19 pandemic and lockdown. Psychiatry Research, 291, 113264.

Human Development Report (2019). Beyond income, beyond averages, beyond today: Inequalities in human development in the 21st century. Retrieved March 11, 2021, from https://reliefweb.int/report/ world/human-development-report-2019-beyond-income-beyondaverages-beyond-today-inequalities\#: :text=The $\% 202019 \%$ 20Human\%20Development\%20Report,necessities\%20to\% 20thrive $\% 20$ have $\% 20$ evolved.

Kundu, P. (2020). Indian education can't go online- only $8 \%$ of homes with young members have computer with net link. Retrieved March 11, 2021, from https://scroll.in/article/960939/indianeducation-cant-go-online-only-8-of-homes-with-school-childrenhave-computer-with-net-link.

Lee, J. (2020). Mental health effects of school closures during COVID19. The Lancet Child \& Adolescent Health, 4(6), 421.

Loades, M. E., Chatburn, E., Higson-Sweeney, N., Reynolds, S., Shafran, R., Brigden, A., Linney, C., McManus, M. N., Borwick, C., \& Crawley, E. (2020). Rapid systematic review: The impact of social isolation and loneliness on the mental health of children and adolescents in the context of COVID-19. Journal of the American Academy of Child and Adolescent Psychiatry, 59(11), 1218-1239.

Nath, A. (2020). Tamil Nadu: Unable to handle stress of online lessons, class 11 student dies by suicide. Retrieved March 11, 2021, from $\mathrm{https}$ ://www.indiatoday.in/india/story/tamil-nadu-unable-to-handlestress-of-online-classes-student-dies-by-suicide-1718084-2020-0903.

Singh, N. (2020). School closure over Covid-19 may cost over USD 400 billion to India: World Bank. Retrieved March 11, 2021, from https://www.hindustantimes.com/india-news/school-closure-overcovid-19-may-cost-over-usd-400-billion-to-india-world-bank/storyhxzbNLnXV46hi0bPyOvfVJ.html.

Publisher's Note Springer Nature remains neutral with regard to jurisdictional claims in published maps and institutional affiliations. 